\title{
Peptide-Au Cluster Probe: Precisely Detecting Epidermal Growth Factor Receptor of Three Tumor Cell Lines at a Single-Cell Level
}

\author{
Jiao Zhai, ${ }^{\dagger}$ Lina Zhao, ${ }^{\dagger}$ Lingna Zheng, ${ }^{\dagger}$ Fuping Gao, ${ }^{\dagger}$ Liang Gao, ${ }^{\dagger}$ Ru Liu, ${ }^{\dagger}$ Yaling Wang, ${ }^{\dagger}$

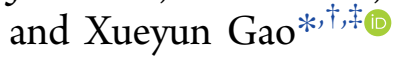

${ }^{\dagger}$ Key Laboratory for Biomedical Effects of Nanomaterials and Nanosafety, Institute of High Energy Physics, Chinese Academy of Sciences, Beijing 100049, China

${ }^{\ddagger}$ Department of Chemistry and Chemical Engineering, Beijing University of Technology, Beijing 100124, China

\section{Supporting Information}

ABSTRACT: Alterations in protein (e.g., biomarkers) expression levels have a significant correlation with tumor development and prognosis; therefore, it is desired to develop precise methods to differentiate the expression level of proteins in tumor cell lines, especially at the single-cell level. Here, we report a precise and versatile approach of quantifying the protein expression levels of three tumor cell lines in situ using a peptide-Au cluster probe. The probe $\left(\mathrm{Au}_{5} \mathrm{Peptide}_{3}\right)$ consists of a peptide with a specific cell membrane epidermal growth factor receptor (EGFR) targeting ability and an Au cluster for both cell membrane EGFR imaging using confocal microscopy and cell membrane EGFR counting by laser ablation inductively coupled plasma mass spectrometry. Utilizing the peptide-Au cluster probe, we successfully quantify the EGFR expression levels of SMMC-7721, KB, and HeLa cells at a single-cell level and differentiate the EGFR expression levels among these cell lines. The peptide-Au cluster probe, with the ability to differentiate the protein expression level of different cell lines,

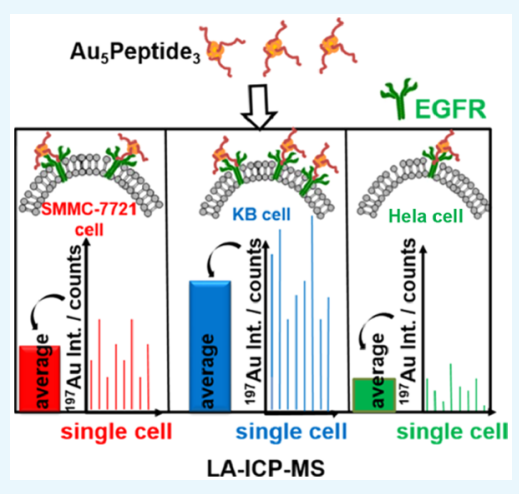
shows exceptional promise for providing reliable predictive and prognostic information of tumors at a single-cell level.

\section{INTRODUCTION}

Characterizing the protein quantity of a single cell can provide valuable insight into the molecular mechanisms of cellular processes, including the cellular heterogeneous response to different chemical drugs and physical stimuli. ${ }^{1,2}$ In clinical settings, information on a specific protein quantity of a single cell can help assess disease progression and prognosis. ${ }^{3,4}$ The epidermal growth factor receptor (EGFR) is an important cellsurface receptor for the maintenance of cell proliferation, differentiation, and survival. ${ }^{5}$ EGFR is overexpressed in many cancers, including head and neck, colon, and breast cancers. ${ }^{6-8}$ In several cancers, such as gastric and colon cancers, EGFR expression is associated with a poor prognosis undergoing a potentially curative surgery. 8,9 Nowadays, EGFR levels are mostly quantified using enzyme immunoassay, western blot, and flow cytometric analyses. ${ }^{6,10,11}$ However, the procedures for these methods are complex. They need cell lysis and protein extraction and can only provide the EGFR level on the basis of the average of large-cell populations. As EGFR is an important biomarker in cancer progression and prognosis, and different cancer cell lines are heterogeneous in the EGFR expression level, ${ }^{9}$ an effective method to differentiate the EGFR expression levels and precisely quantify the EGFR of different cell lines at a single-cell level is desired.

Recently, some single-cell protein analysis methods have emerged. These methods were based on an antibody conjugated with lanthanide ions, and the specific protein expression level in the single cell was obtained by counting lanthanide ions using mass cytometry. ${ }^{12,13}$ However, antibodybased protein quantification methods have some shortcomings. For example, it is difficult to precisely control the number of lanthanide ions conjugated to the antibody, ${ }^{14-16}$ thus it is hard to determine the precise protein level in a single cell. In addition, the antibody is expensive. With the advantage of low immunogenicity, ease in synthesis, and low cost, peptide ligands have been pursued as a target moiety for certain proteins. In this article, we developed a new peptide-Au cluster probe to quantify EGFR in a single cell. Our peptide-Au cluster is relatively cheap and easily synthesized when compared with an antibody. In addition, in a single probe there are exactly five gold atoms; thus we can count more precisely the protein expression level in a single cell.

It is reported that EGFR overexpression is correlated with hepatocellular carcinoma, ${ }^{17-19}$ nasopharyngeal carcinoma, ${ }^{20,21}$ and cervical cancers. ${ }^{22,23}$ SMMC-7721, KB, and HeLa cells are the cells associated with the aforementioned hepatocellular carcinoma, nasopharyngeal carcinoma, and cervical cancer, respectively. The information on EGFR expression in the three cell lines is important for cancer diagnosis and therapy. Therefore, these three tumor cell lines (SMMC-7721, KB, and HeLa cells) were chosen for EGFR studies. We designed a peptide-Au cluster probe $\left(\mathrm{Au}_{5}\right.$ Peptide 3$)$, with a fluorescent

Received: November 12, 2016

Accepted: January 10, 2017

Published: January 27, 2017 

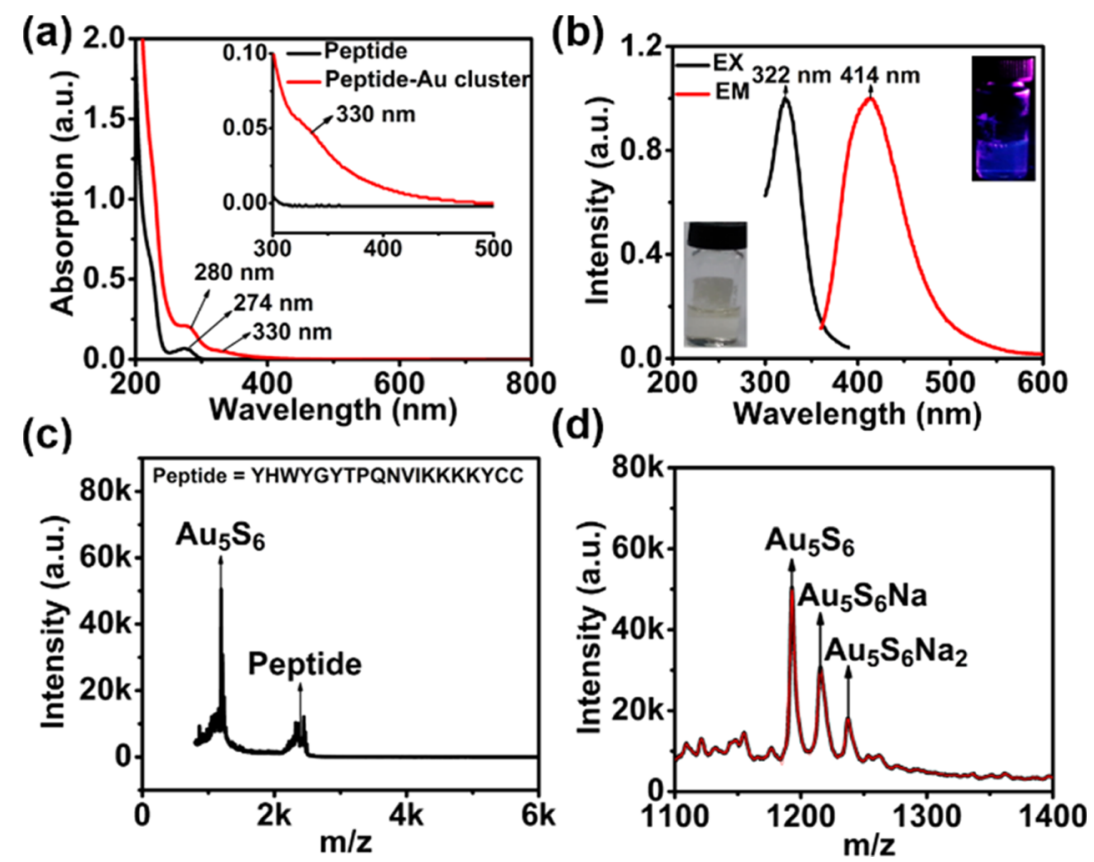

Figure 1. (a) UV-vis absorption spectrum of the peptide-Au cluster probe, the inset is an enlarged view between 300 and $500 \mathrm{~nm}$. (b) Excitation and emission spectra of the peptide-Au cluster. Inset: Digital photographs taken without (lower left) and with (upper right) UV light irradiation $(365 \mathrm{~nm})$. (c) MALDI-TOF-MS of the peptide-Au cluster from 0 to $6000 \mathrm{~m} / z$ (S, sulfur atom). (d) Enlarged view of the peptide-Au cluster mass spectra range from 1100 to $1400 \mathrm{~m} / z$.

property and a specific EGFR-targeting ability, to realize EGFR visualization in these cell lines by confocal microscopy. Then, with the help of laser ablation inductively coupled plasma mass spectrometry (LA-ICP-MS) and the molecular formula of our probe $\left(\mathrm{Au}_{5} \mathrm{Peptide}_{3}\right)$, we could precisely quantify EGFR in a single SMMC-7721, KB, and HeLa cell by counting the $\mathrm{Au}$ element of the EGFR-binding peptide-Au cluster.

\section{RESULTS AND DISCUSSION}

The peptide $\mathrm{H}_{2} \mathrm{~N}-\mathrm{YHWYGYTPQNVIKKKKYCC}-\mathrm{COOH}$, with two functional domains, was designed. YHWYGYTPQN$\mathrm{VI}$ is a specific target sequence for EGFR. ${ }^{24}$ KKKKYCC was added to the carboxyl terminal of the target sequence. KKKK was added to increase the solubility of the sequence, whereas YCC was added for capturing the $\mathrm{Au}$ cluster. The specific synthetic process is described in Experimental Procedures.

After obtaining our probe, we analyzed its absorption, fluorescence, and mass spectra. Compared to the UV-vis spectra of the free peptide (Figure 1a, black line), we found that a new absorption band appears at $330 \mathrm{~nm}$, in accordance with the maximum excitation at $322 \mathrm{~nm}$ (Figure 1b, black line). The probe showed maximum emission at $414 \mathrm{~nm}$ (Figure $1 \mathrm{~b}$, red line) and strong blue fluorescence under UV irradiation of 365 $\mathrm{nm}$ (inset of Figure $1 \mathrm{~b}$ ). To quantify EGFR in a single cell accurately, we needed to acquire the precise composition of our probe. Matrix-assisted laser desorption/ionization time of flight mass spectrometry (MALDI-TOF-MS) is a popular method for studying the accurate mass of a noble metal cluster. ${ }^{25-27}$ As shown in Figure 1c,d, the peptide-Au cluster is mainly composed of fragments of $\mathrm{Au}_{5}$ plus six $\mathrm{S}$ atoms. We cannot see the intact peptide-Au cluster composition (Figure 1c,d), as the $\mathrm{C}-\mathrm{S}$ bond of the peptide is easily broken during the desorption process. ${ }^{28,29}$ The mass spectral data in Figure 1d suggested that the composition of our probe fragment is $\mathrm{Au}_{5} \mathrm{~S}_{6}$. As each peptide is with two Cys, for example, two $S$ atoms, we deduce that the probe formula is $\mathrm{Au}_{5}$ Peptide $_{3}$.

To mark and quantify EGFR precisely, the specificity of the probe needed to be confirmed first. Figure S1 in the Supporting Information suggests that our probe can mark SMMC-7721, $\mathrm{KB}$, and HeLa cells. To confirm the specific EGFR recognition of our probe, immunofluorescence assays and blocking studies were further carried out. The blue fluorescence of the probe and the red fluorescence of the EGFR antibody were well colocalized on the membranes of the SMMC-7721, KB, and HeLa cells, as depicted in Figure $2 \mathrm{a}-\mathrm{c}$, respectively. In the blocking study, we failed to see any obvious probe fluorescence on the membranes of the SMMC-7721, KB, and HeLa cells after the EGFR of these cell lines were first blocked by $5 \mathrm{mM}$ free peptides, because the binding site of EGFR had been occupied by the free peptides (Figure $2 \mathrm{~d}-\mathrm{f}$ ). All of the results support the EGFR specificity recognition of our probes.

We needed to confirm the optimal labeling parameter before quantifying EGFR in the three cell lines. In this study, solutionbased ICP-MS was carried out to obtain the proper probe and cell incubation conditions. Figure $3 a-c$ suggests that the $\mathrm{Au}$ mass per cell was saturated when the probe reached $1.87 \mu \mathrm{M}$ and after $1 \mathrm{~h}$ of incubation time. The time parameter of cell labeling was then carried out. Figure $3 \mathrm{~d}-\mathrm{f}$ shows that the optimal labeling time was $1 \mathrm{~h}$ when the probe concentration was $1.87 \mu \mathrm{M}$. All of these results suggest that the optimal labeling condition to count EGFR in the cells was $1.87 \mu \mathrm{M}$ and $1 \mathrm{~h}$.

According to Figure $3 \mathrm{a}-\mathrm{f}$, under the optimal labeling conditions, the average $\mathrm{Au}$ mass in SMMC-7721, KB, and HeLa cells was about $11.35 \pm 0.81,33.89 \pm 1.61$, and $8.45 \pm$ $0.45 \mathrm{fg}$, respectively.

As one probe contained $5 \mathrm{Au}$ atoms, the number of probe molecules in one SMMC-7721, KB, and HeLa cell was about $11.35 \pm 0.81,33.89 \pm 1.61$, and $8.45 \pm 0.45$ amol, respectively, 
(a)
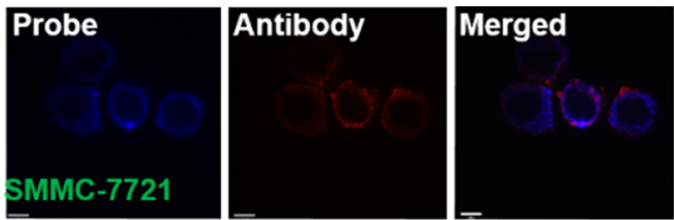

(b)
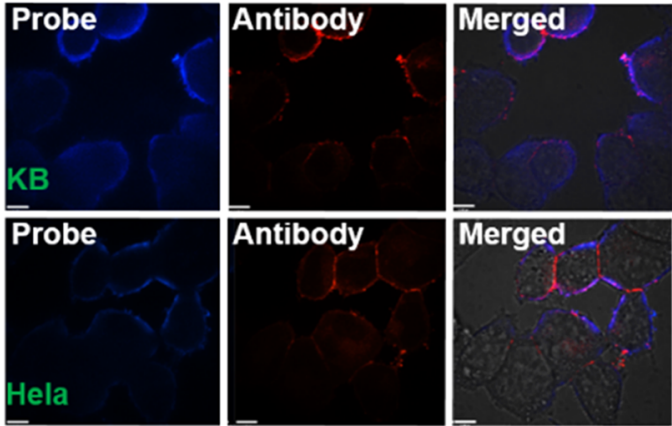

(c)
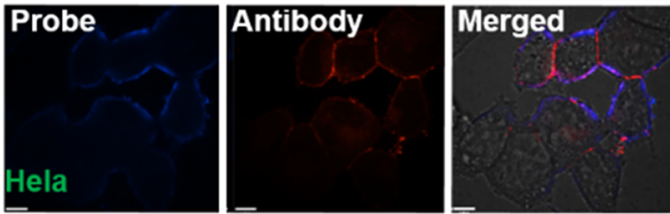

(d)
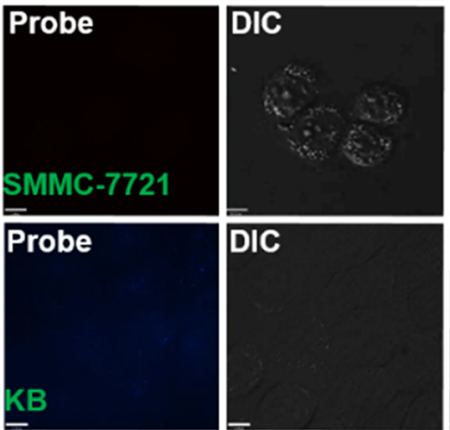

Merged

(e)

(f)
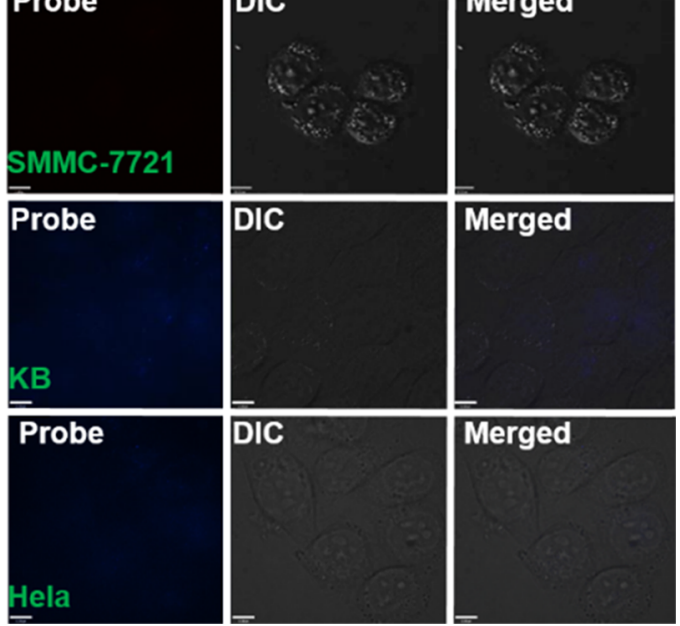

Figure 2. $\mathrm{Au}_{5} \mathrm{Peptide}_{3}$ probe-specific marking of EGFR of three cell lines. Confocal fluorescence images of the three cell lines exposed to $(\mathrm{a}-\mathrm{c})$ the $\mathrm{Au}_{5} \mathrm{Peptide}_{3}$ probe, followed by the EGFR antibody (mouse monoclonal antibody) and the goat antimouse IgG-TR, (d-f) $5 \mathrm{mM}$ free peptide incubated first with the cells for $1 \mathrm{~h}$, followed by the $\mathrm{Au}_{5}$ Peptide $_{3}$ probe incubated for $45 \mathrm{~min}$.

which is equal to the amount of EGFR in a single SMMC-7721, $\mathrm{KB}$, and HeLa cell (Figure 4a). We then used Western blotting to confirm the accuracy of our method to differentiate EGFR expression levels in the three cell lines. According to Figure $4 b$, $\mathrm{KB}$ cells express the highest levels of EGFR among the three cell lines, followed by SMMC-7721 cells and then HeLa cells. The result of the Western blot analysis suggests the feasibility of our method to differentiate different EGFR levels in the three cell lines.

To further check the EGFR expression level in a single cell, we used LA-ICP-MS to quantify the abundance of $\mathrm{Au}$ (which can be precisely switched to the EGFR amount by the probe formula) under the optimized labeling conditions. The operation conditions for LA-ICP-MS is shown in Table S1. Figure $5 \mathrm{a}-\mathrm{f}$ shows the transient $\mathrm{Au}$ signals of the three cell lines determined by LA-ICP-MS without probe treatment (ac) and under the optimized probe labeling conditions (d-f). To obtain the relationship between the Au signal intensity and the Au concentration in a single cell, we used MicroFabJetLab (a commercial inkjet printer) as our calibration standard. ${ }^{30,31}$ The ${ }^{197} \mathrm{Au}$ signal intensity from ablation of different contents of $\mathrm{Au}$ standards on glass slides and the corresponding calibration curve are shown in Figure S2. According to the Au standard calibration curve and three kinds of control cells (Figure 5a-c), we can regard the $\mathrm{Au}$ signal intensities under the optimized incubation conditions (Figure $5 \mathrm{~d}-\mathrm{f}$ ) as a response to our probe (note that we first integrated the peak areas and then compared it to that of the calibration curve).

Under the optimal incubation condition, the mass of $\mathrm{Au}$ in a single cell ranged from 5.75 to $20.45 \mathrm{fg}$ for SMMC-7721 cells, 16.95 to $44.69 \mathrm{fg}$ for $\mathrm{KB}$ cells, and 1.88 to $15.19 \mathrm{fg}$ for HeLa cells (see details in Figures $5 \mathrm{~d}-\mathrm{f}$ and $\mathrm{S} 2$ ). As one probe contains $5 \mathrm{Au}$ atoms, the amount of probe (equal to the number of EGFR) of 35 cells on a single cell was from 5.75 to 20.5 amol for SMMC-7721 cells, 17 to 44.7 amol for KB cells, and 1.88 to 15.2 amol for HeLa cells. The average EGFR amount in Figure $5 \mathrm{~d}-\mathrm{f}$ was $13 \pm 3.8$ amol for SMMC-7721 cells, $34 \pm 7.7 \mathrm{amol}$ for $\mathrm{KB}$ cells, and $7.3 \pm 3.6 \mathrm{amol}$ for HeLa cells. These results were close to the result of $11.35 \pm 0.81$ amol for SMMC-7721 cells, $33.89 \pm 1.61$ amol for KB cells, and $8.45 \pm 0.45$ amol for HeLa cells per cell determined from the bulk cell digestion method in Figure 4a.

\section{CONCLUSIONS}

In conclusion, utilizing the probe, we successfully quantified three cell lines with different EGFR expression levels in a single cell. The trend of the average EGFR expression levels in the three cell lines obtained from LA-ICP-MS is in accordance with the commonly used protein quantification method, Western blot, which suggests the reliability of our probe to differentiate cells with different protein expression levels. The broad spectrum activity of our probe to quantify proteins in different cell lines makes it possible to differentiate a specific protein of multiple tumor cell lines. As the variation of a protein quantity at a single-cell level has a significant correlation with the early progression of a tumor cell, our methods can help estimate the earlier tumor development at a single-cell level.

\section{EXPERIMENTAL PROCEDURES}

Materials. Peptide YHWYGYTPQNVIKKKKYCC (purity: 95\%) was purchased from China Peptides. The Centrifugal Filters (MWCO: $3 \mathrm{kDa}$ ) were purchased from Merck. Paraformaldehyde was purchased from Sigma. The KB cell line was purchased from Cancer Institute and Hospital, Chinese Academy of Medical Sciences. The SMMC-7721 cell line was a gift from Prof. Zonghai Li, Shanghai Cancer Institute. The cell culture medium RPMI Medium Modified, DMEM/High Glucose, and the Phosphate buffer solution were purchased from Hyclone. Fetal bovine serum (FBS) was purchased from Gibco. EGFR antibody (sc-365829) and goat antimouse IgGTR (sc-2781) were purchased from Santa Cruz Biotechnology. All of the other materials were commercially available.

Preparation of the Peptide-Au Cluster Probe. The peptide solution $(1 \mathrm{mM}, 515 \mu \mathrm{L})$ was prepared by dissolving it in ultrapure water. $\mathrm{NaOH}$ was used to adjust the $\mathrm{pH}$ to 10 . (The whole preparation process was carried out at $42{ }^{\circ} \mathrm{C}$.) After stirring for $5 \mathrm{~min}, \mathrm{HAuCl}_{4}(25 \mathrm{mM}, 10 \mu \mathrm{L})$ aqueous solution was introduced under vigorous stirring. Subsequently, the $\mathrm{pH}$ of the solution was adjusted to 14 by $\mathrm{NaOH}$ and incubated for $12 \mathrm{~h}$. Finally, the probe was stored away from light at $4{ }^{\circ} \mathrm{C}$. Before being used in the subsequent experiments, the probe was dialyzed at $3 \mathrm{kDa}$ to remove the free ions and peptides. 

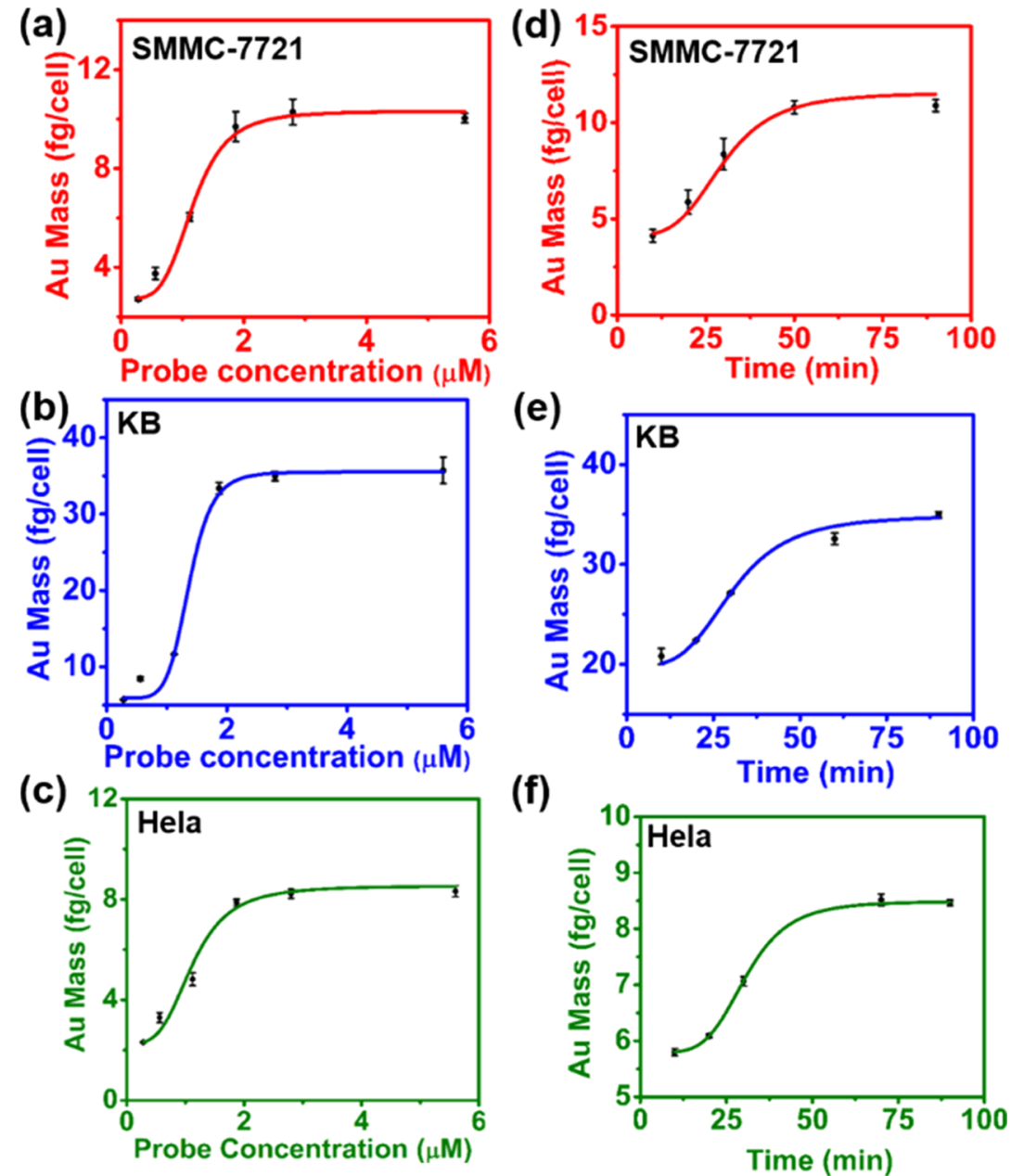

Figure 3. Average mass of Au per cell was determined by ICP-MS to optimize the cell label conditions in three cell lines exposed to (a-c) a series of concentrations of the peptide-Au cluster probe in a Roswell Park Memorial Institute (RPMI) medium for $1 \mathrm{~h}$ and $(\mathrm{d}-\mathrm{f})$ the probe of $1.87 \mu \mathrm{M}($ the optimized concentration) for different time points.
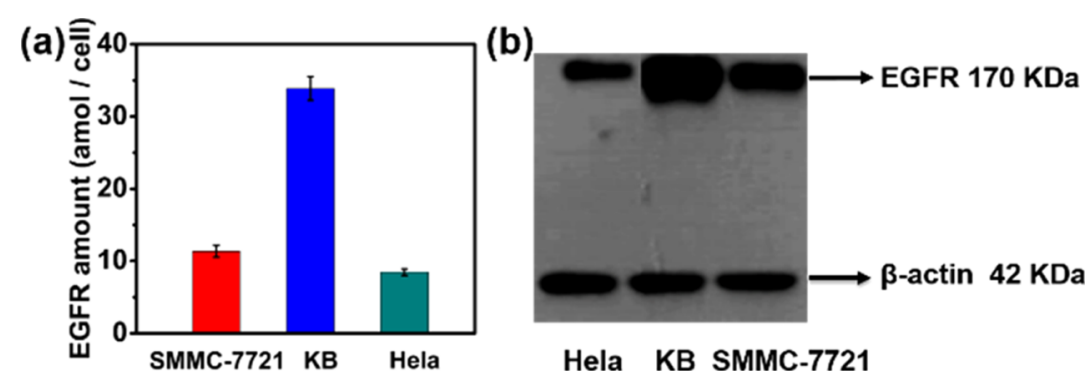

Figure 4. (a) Average EGFR in a single SMMC-7721, KB, and HeLa cell. (b) Western blot of EGFR and $\beta$-actin extracted from HeLa, KB, and SMMC-7721 cells. $\beta$-Actin is used as a control to ensure the accuracy of immunoblotting.

Characterization of the Peptide-Au Cluster Probe: Product Yield of the Peptide-Au Cluster Probe. We used ICP-MS to measure the product yield of the peptide-Au cluster probe. First, the probe was purified using a dialysis tube (MWCO: $3 \mathrm{kDa}$ ) to remove the free ions and peptides. Then, 1 $\mathrm{mL}$ nitric acid and $3 \mathrm{~mL}$ hydrochloric acid were added to the purified and crude samples overnight. (All of the samples were run in triplicate.) Subsequently, we used the Microwave Reactions System to digest the samples and diluted them with an aqueous solution containing $2 \% \mathrm{HNO}_{3}$ and $1 \% \mathrm{HCl}$. Then, a series of Au standard solutions $(0.5,1,5,10,50 \mathrm{ng} / \mathrm{mL}$ aqueous solution containing $2 \% \mathrm{HNO}_{3}$ and $1 \% \mathrm{HCl}$ ) was injected into the ICP-MS system to get the standard calibration plot. Finally, the purified and crude samples were also injected into the ICP-MS system. The product yield of the peptide- $\mathrm{Au}$ cluster probe was $42.15 \%$.

Optical Spectra Study of the Peptide-Au Cluster Probe: Absorption Spectra Study. The peptide-Au cluster probe was diluted with Milli-Q water and then used for absorption spectra study. The reference solution was Milli- $\mathrm{Q}$ water. We obtained the spectra using a spectrophotometer (UV-1800; Shimadzu, Japan). 
(a)

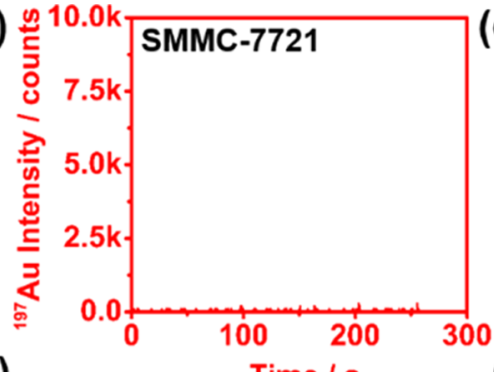

(b)

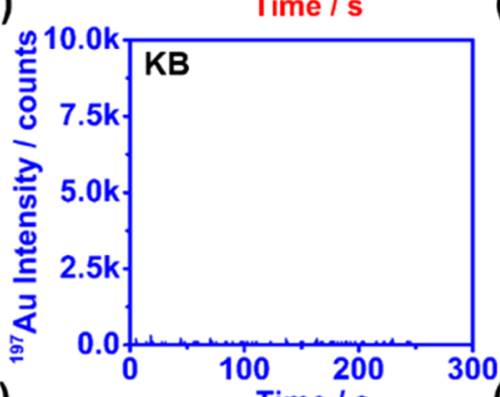

(c)

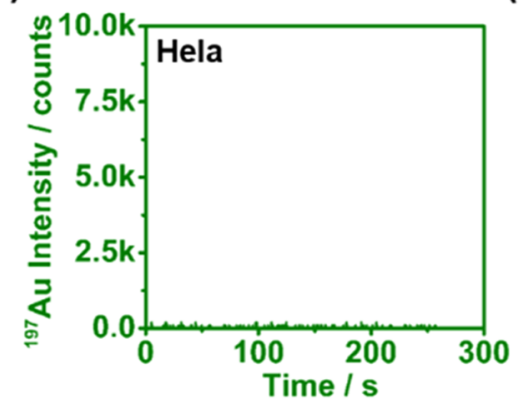

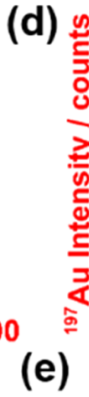
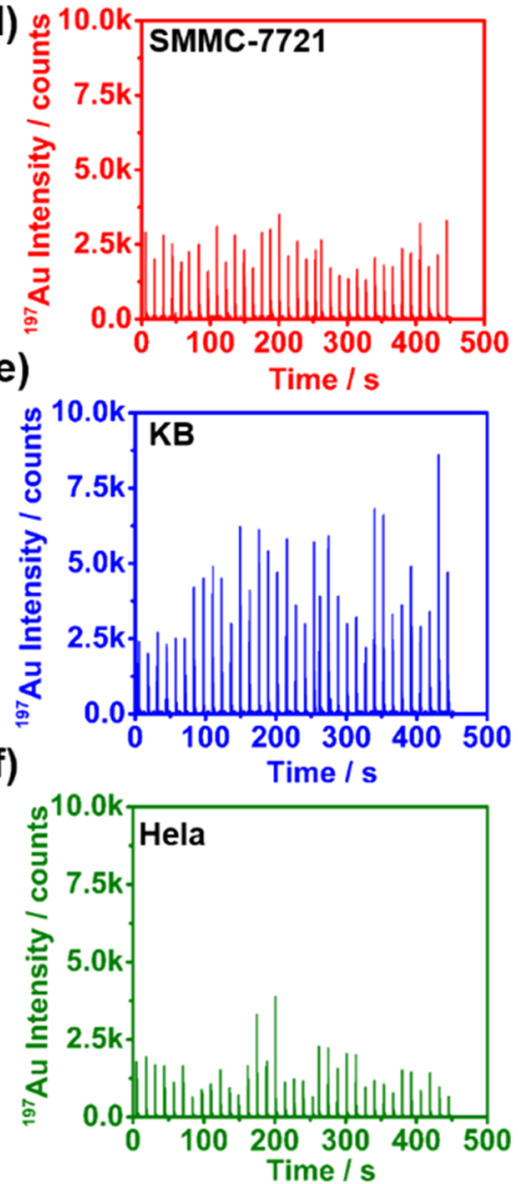

Figure 5. Transient Au signals of the three cell lines determined by LA-ICP-MS $(a-c)$ without any probe treatment and $(d-f)$ under the optimal probe incubation conditions.

Fluorescent Spectra Study. We used a spectrofluorometer (RF-5301; Shimadzu, Japan) to obtain the fluorescence spectra of our probe.

MALDI-TOF-MS Study of the Peptide-Au Cluster Probe. The mass spectra were obtained by the ABI MALDITOF system in a linear positive mode with the matrix CHCA.

Specific Study of the Probe for EGFR in SMMC-7721, $K B$, and HeLa Cells: Cell Location Study of the Probe in SMMC-7721, KB, and HeLa Cells. The SMMC-7721, KB, and HeLa cells were cultured on a glass-bottomed culture dish and incubated at $37{ }^{\circ} \mathrm{C}$ for $24 \mathrm{~h}$. After being washed with PBS twice and fixed with $3.7 \%$ paraformaldehyde at room temperature for $20 \mathrm{~min}$, the cells were incubated with the probe for $45 \mathrm{~min}$. Then, we washed them with PBS twice to remove the free probes. Finally, the cells were observed under a fluorescence microscope (Perkin Elmer Spinning Disc confocal microscope with a Nikon TI-E inverted microscope, $60 \times$ oil immersion lens was used), and pictures were acquired by UltraVIEW VoX software.

Probe and EGFR Antibody Co-Localization Study in SMMC-7721, KB, and HeLa Cells. To make sure the probe marked EGFR specifically, anti-EGFR antibody was used. First, the cells were fixed with $3.7 \%$ paraformaldehyde for $20 \mathrm{~min}$ and incubated with the probe for $45 \mathrm{~min}$. Second, the cells were washed with PBS three times and incubated with the antiEGFR antibody (sc-365829) in PBS for $45 \mathrm{~min}$ and, subsequently, in a second antibody (sc-2781) for $35 \mathrm{~min}$ away from light. After that, we used PBS to wash the cells three times. Finally, the cells were observed under a confocal microscope.

Blocking Study. To further confirm the specificity of our probe to EGFR, the cells were fixed in $3.7 \%$ paraformaldehyde for $20 \mathrm{~min}$ at room temperature and then incubated with $5 \mathrm{mM}$ peptide for $1 \mathrm{~h}$. After washing with PBS three times, the cells were incubated with the probe at room temperature for $45 \mathrm{~min}$. Finally, the cells were observed under a confocal microscope.

Quantifying the Expression Level of EGFR in SMMC7721, KB, and HeLa Cells. To get the optimal labeling condition, we first allowed a series of probe concentrations $(0.28,0.56,1.12,1.87,2.8,5.6 \mu \mathrm{M})$ to be incubated with SMMC-7721, KB, and HeLa cells for $1 \mathrm{~h}$ at room temperature. We then used PBST (a strong wash solution) to wash our samples 5 times and then counted using flow cytometry. Subsequently, these samples were transferred to MARS Vessels. In all of the vessels, $3 \mathrm{~mL}$ of nitric acid and $1 \mathrm{~mL}$ of hydrogen peroxide were added individually. After $24 \mathrm{~h}$, these samples were digested against the Microwave Reactions System (CEM Co. MARS Xpress). After that, $1 \mathrm{~mL}$ of nitric acid and $3 \mathrm{~mL}$ of hydrochloric acid were added. The samples were then digested again using the Microwave Reactions System after $24 \mathrm{~h}$. Ultimately, an aqueous solution containing $2 \% \mathrm{HNO}_{3}$ and $1 \%$ $\mathrm{HCl}$ was added to $3 \mathrm{~mL}$ as the final volume. Then, we got the $\mathrm{Au}$ standard Calibration plot by injecting a series of $\mathrm{Au}$ standard solutions $(0.5,1,5,10,50 \mathrm{ng} / \mathrm{mL}$ in an aqueous solution containing $2 \% \mathrm{HNO}_{3}$ and $1 \% \mathrm{HCl}$ ). All of the samples were run in triplicate. We then studied the time impact on the 
labeling efficiency. SMMC-7721, KB, and HeLa cells were incubated with $1.87 \mu \mathrm{M}$ of the probe at different times $(10,20$, $40,60,70,90 \mathrm{~min})$ at room temperature. The other operation steps were the same as the ones in the study of the concentration effect on the labeling efficiency.

Semiquantitative Study of the EGFR Expression Levels in SMMC-7721, KB, and HeLa Cells by Western Blot. SMMC-7721, KB, and HeLa cells were seeded into a 6well plate. After $24 \mathrm{~h}$, the cells were lysed with $200 \mu \mathrm{L}$ RIPA buffer ( $50 \mathrm{mM}$ Tris-HCl, pH 7.4, $150 \mathrm{mM} \mathrm{NaCl}, 1 \%$ Triton $\mathrm{X}-100,1 \%$ sodium deoxycholate, $0.1 \%$ sodium dodecyl sulfate (SDS), $1 \mathrm{mM}$ sodium orthovanadate, $50 \mathrm{mM} \mathrm{NaF}$, and $1 \mathrm{mM}$ ethylenediaminetetraacetic acid) and a protease inhibitor cocktail tablet (Roche Molecular Biochemicals) for $10 \mathrm{~min}$ at $4{ }^{\circ} \mathrm{C}$. Then, we collected the cell supernatant by centrifugation at $12000 \mathrm{rpm}$ for $5 \mathrm{~min}$ at $4{ }^{\circ} \mathrm{C}$. The protein concentrations of the four samples were measured by the BCA assay kit (Beyotime). The samples were then mixed with $4 \times$ loading buffer, heated at $100{ }^{\circ} \mathrm{C}$ for $5 \mathrm{~min}$, and subjected to $12 \%$ SDSpolyacrylamide gel electrophoresis (the proteins loaded across the lanes were equal). Finally, the proteins were transferred to the PVDF membrane and probed with specific antibodies, and protein bands were detected using the Amersham ECLTM Prime Western Blotting Detection Reagent (GE healthcare, U.K.).

Quantification of EGFR in Individual SMMC-7721, KB, and HeLa Cells by LA-ICP-MS. In the experiment, a 213 laser ablation system (ESI, Fremont) coupled to a NexION 300D ICPMS instrument (PerkinElmer, Norwalk) was used. We used helium (the flow rate was $0.8 \mathrm{~L} / \mathrm{min}$ ) as the ablation gas. Argon was introduced through a Y-piece after the cell was ablated. During the ablation of the NIST 611 glass, the system was tuned for a maximum ${ }^{115}$ In signal intensity, and the UO/U ratio was kept at a low level simultaneously. The operational parameters of LA-ICP-MS are given in Table S1. The STD mode was used, and the signal intensity (counts/s) was collected. In the experiment, SMMC-7721, KB, and HeLa cells were seeded into a 12-well cell culture cluster. After $12 \mathrm{~h}, 1.87$ $\mu \mathrm{M}$ of the probe was incubated with the three types of cells for $1 \mathrm{~h}$. Then, PBST was used to wash the cells 5 times. After the cells were dried, we introduced them into LA-ICP-MS. A 40 $\mu \mathrm{m}$ diameter area was chosen to ensure the cell was completely covered. The Au standards (2.54, 14.86, 28.93, and $133.03 \mathrm{fg}$ ) were analyzed individually with the same experimental procedures in the sample analysis.

\section{ASSOCIATED CONTENT}

\section{S Supporting Information}

The Supporting Information is available free of charge on the ACS Publications website at DOI: 10.1021/acsomega.6b00390.

Cell location study, operating conditions for LA-ICP-MS, and single-cell Au calibration standard curve (PDF)

\section{AUTHOR INFORMATION}

\section{Corresponding Author}

*E-mail: gaoxy@ihep.ac.cn.

\section{ORCID}

Xueyun Gao: 0000-0002-2267-9945

\section{Notes}

The authors declare no competing financial interest.

\section{ACKNOWLEDGMENTS}

This work was financially supported by the National Key Basic Research Program of China (2013CB932703, 2013CB933704) and the National Science Foundation of China (21425522, 21390414).

\section{REFERENCES}

(1) Wu, M. Y.; Singh, A. K. Single-cell protein analysis. Curr. Opin. Biotechnol. 2012, 23, 83-88.

(2) Tay, S.; Hughey, J. J.; Lee, T. K.; Lipniacki, T.; Quake, S. R.; Covert, M. W. Single-cell NF-kappa B dynamics reveal digital activation and analogue information processing. Nature 2010, 466, 267-271.

(3) Shackleton, M.; Quintana, E.; Fearon, E. R.; Morrison, S. J. Heterogeneity in Cancer: Cancer Stem Cells versus Clonal Evolution. Cell 2009, 138, 822-829.

(4) Yu, M.; Stott, S.; Toner, M.; Maheswaran, S.; Haber, D. A. Circulating tumor cells: approaches to isolation and characterization. J. Cell Biol. 2011, 192, 373-382.

(5) Yewale, C.; Baradia, D.; Vhora, I.; Patil, S.; Misra, A. Epidermal growth factor receptor targeting in cancer: a review of trends and strategies. Biomaterials 2013, 34, 8690-707.

(6) Ciardiello, F.; Tortora, G. Epidermal growth factor receptor (EGFR) as a target in cancer therapy: understanding the role of receptor expression and other molecular determinants that could influence the response to anti-EGFR drugs. Eur. J. Cancer 2003, 39, $1348-1354$.

(7) Nicholson, R. I.; Gee, J. M. W.; Harper, M. E. EGFR and cancer prognosis. Eur. J. Cancer 2001, 37, 9-15.

(8) Galizia, G.; Lieto, E.; Orditura, M.; Castellano, P.; La Mura, A.; Imperatore, V.; Pinto, M.; Zamboli, A.; De Vita, F.; Ferraraccio, F. Epidermal growth factor receptor (EGFR) expression is associated with a worse prognosis in gastric cancer patients undergoing curative surgery. World J. Surg. 2007, 31, 1458-1468.

(9) Galizia, G.; Lieto, E.; Ferraraccio, F.; De Vita, F.; Castellano, P.; Orditura, M.; Imperatore, V.; La Mura, A.; La Manna, G.; Pinto, M.; Catalano, G.; Pignatelli, C.; Ciardiello, F. Prognostic significance of epidermal growth factor receptor expression in colon cancer patients undergoing curative surgery. Ann. Surg. Oncol. 2006, 13, 823-835.

(10) Gao, J.; Yu, Y. S.; Zhang, Y. Y.; Song, J. J.; Chen, H. W.; Li, W.; Qian, W. Z.; Deng, L.; Kou, G.; Chen, J. M.; Guo, Y. J. EGFR-specific PEGylated immunoliposomes for active siRNA delivery in hepatocellular carcinoma. Biomaterials 2012, 33, 270-282.

(11) Psyrri, A.; Bamias, A.; Yu, Z. W.; Weinberger, P. M.; Kassar, M.; Markakis, S.; Kowalski, D.; Efstathiou, E.; Camp, R. L.; Rimm, D. L.; Dimopoulos, M. A. Subcellular localization and protein levels of cyclindependent kinase inhibitor p27 independently predict for survival in epithelial ovarian cancer. Clin. Cancer Res. 2005, 11, 8384-8390.

(12) Bendall, S. C.; Simonds, E. F.; Qiu, P.; Amir, E. A. D.; Krutzik, P. O.; Finck, R.; Bruggner, R. V.; Melamed, R.; Trejo, A.; Ornatsky, O. I.; Balderas, R. S.; Plevritis, S. K.; Sachs, K.; Pe'er, D.; Tanner, S. D.; Nolan, G. P. Single-Cell Mass Cytometry of Differential Immune and Drug Responses Across a Human Hematopoietic Continuum. Science 2011, 332, 687-696.

(13) Heath, J. R.; Ribas, A.; Mischel, P. S. Single-cell analysis tools for drug discovery and development. Nat. Rev. Drug Discovery 2016, 15, 204-216.

(14) Bodenmiller, B.; Zunder, E. R.; Finck, R.; Chen, T. J.; Savig, E. S.; Bruggner, R. V.; Simonds, E. F.; Bendall, S. C.; Sachs, K.; Krutzik, P. O.; Nolan, G. P. Multiplexed mass cytometry profiling of cellular states perturbed by small-molecule regulators. Nat. Biotechnol. 2012, $30,858-867$.

(15) Bjornson, Z. B.; Nolan, G. P.; Fantl, W. J. Single-cell mass cytometry for analysis of immune system functional states. Curr. Opin. Immunol. 2013, 25, 484-494.

(16) Ornatsky, O.; Bandura, D.; Baranov, V.; Nitz, M.; Winnik, M. A.; Tanner, S. Highly multiparametric analysis by mass cytometry. J. Immunol. Methods 2010, 361, 1-20. 
(17) Gao, J.; Yu, Y.; Zhang, Y.; Song, J.; Chen, H.; Li, W.; Qian, W.; Deng, L.; Kou, G.; Chen, J.; Guo, Y. EGFR-specific PEGylated immunoliposomes for active siRNA delivery in hepatocellular carcinoma. Biomaterials 2012, 33, 270-282.

(18) Wang, H.; Jiang, H.; Zhou, M.; Xu, Z.; Liu, S.; Shi, B.; Yao, X.; Yao, M.; Gu, J.; Li, Z. Epidermal growth factor receptor vIII enhances tumorigenicity and resistance to 5-fluorouracil in human hepatocellular carcinoma. Cancer Lett. 2009, 279, 30-38.

(19) Han, C.; Michalopoulos, G. K.; Wu, T. Prostaglandin E2 receptor EP1 transactivates EGFR/MET receptor tyrosine kinases and enhances invasiveness in human hepatocellular carcinoma cells. J. Cell. Physiol. 2006, 207, 261-270.

(20) Ma, B. B.; Poon, T. C.; To, K.; Zee, B.; Mo, F. K.; Chan, C. M.; Ho, S.; Teo, P. M.; Johnson, P. J.; Chan, A. T. Prognostic significance of tumor angiogenesis, $\mathrm{Ki} 67, \mathrm{p} 53$ oncoprotein, epidermal growth factor receptor and HER2 receptor protein expression in undifferentiated nasopharyngeal carcinoma-a prospective study. Head Neck 2003, 25, 864-872.

(21) Chua, D. T.; Wei, W. I.; Wong, M. P.; Sham, J. S.; Nicholls, J.; $\mathrm{Au}, \mathrm{G}$. K. Phase II study of gefitinib for the treatment of recurrent and metastatic nasopharyngeal carcinoma. Head Neck 2008, 30, 863-867.

(22) Iida, K.; Nakayama, K.; Rahman, M. T.; Rahman, M.; Ishikawa, M.; Katagiri, A.; Yeasmin, S.; Otsuki, Y.; Kobayashi, H.; Nakayama, S.; Miyazaki, K. EGFR gene amplification is related to adverse clinical outcomes in cervical squamous cell carcinoma, making the EGFR pathway a novel therapeutic target. Br. J. Cancer 2011, 105, 420-427.

(23) Soonthornthum, T.; Arias-Pulido, H.; Joste, N.; Lomo, L.; Muller, C.; Rutledge, T.; Verschraegen, C. Epidermal growth factor receptor as a biomarker for cervical cancer. Ann. Oncol. 2011, 22, 2166-2178.

(24) Li, Z. H.; Zhao, R. J.; Wu, X. H.; Sun, Y.; Yao, M.; Li, J. J.; Xu, Y. $\mathrm{H}$.; Gu, J. R. Identification and characterization of a novel peptide ligand of epidermal growth factor receptor for targeted delivery of therapeutics. FASEB J. 2005, 19, 1978-1985.

(25) Xie, J. P.; Zheng, Y. G.; Ying, J. Y. Protein-Directed Synthesis of Highly Fluorescent Gold Nanoclusters. J. Am. Chem. Soc. 2009, 131, 888-889.

(26) Arnold, R. J.; Reilly, J. P. High-resolution time-of-flight mass spectra of alkanethiolate-coated gold nanocrystals. J. Am. Chem. Soc. 1998, 120, 1528-1532.

(27) Le Guevel, X.; Hotzer, B.; Jung, G.; Hollemeyer, K.; Trouillet, V.; Schneider, M. Formation of Fluorescent Metal ( $\mathrm{Au}, \mathrm{Ag}$ ) Nanoclusters Capped in Bovine Serum Albumin Followed by Fluorescence and Spectroscopy. J. Phys. Chem. C 2011, 115, 1095510963.

(28) Negishi, Y.; Nobusada, K.; Tsukuda, T. Glutathione-protected gold clusters revisited: Bridging the gap between gold(I)-thiolate complexes and thiolate-protected gold nanocrystals. J. Am. Chem. Soc. 2005, 127, 5261-5270.

(29) Yu, Y.; Luo, Z. T.; Chevrier, D. M.; Leong, D. T.; Zhang, P.; Jiang, D. E.; Xie, J. P. Identification of a Highly Luminescent Au22(SG)(18) Nanocluster. J. Am. Chem. Soc. 2014, 136, 1246-1249.

(30) Zhai, J.; Wang, Y.; Xu, C.; Zheng, L.; Wang, M.; Feng, W.; Gao, L.; Zhao, L.; Liu, R.; Gao, F.; Zhao, Y.; Chai, Z.; Gao, X. Facile approach to observe and quantify the alpha(IIb)beta3 integrin on a single-cell. Anal. Chem. 2015, 87, 2546-2549.

(31) Wang, M.; Zheng, L. N.; Wang, B.; Chen, H. Q.; Zhao, Y. L.; Chai, Z. F.; Reid, H. J.; Sharp, B. L.; Feng, W. Y. Quantitative Analysis of Gold Nanoparticles in Single Cells by Laser Ablation Inductively Coupled Plasma-Mass Spectrometry. Anal. Chem. 2014, 86, 1025210256 . 